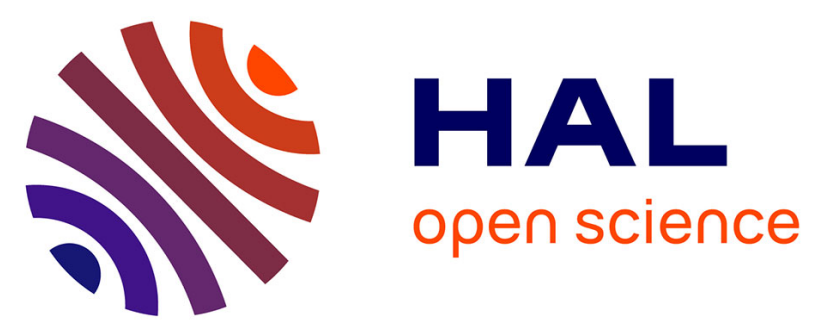

\title{
Syntectonic mobility of supergene nickel ores of New Caledonia (Southwest Pacific). Evidence from faulted regolith and garnierite veins.
}

\author{
Dominique Cluzel, Benoit Vigier
}

\section{- To cite this version:}

Dominique Cluzel, Benoit Vigier. Syntectonic mobility of supergene nickel ores of New Caledonia (Southwest Pacific). Evidence from faulted regolith and garnierite veins.. Resource Geology, 2008, 58 (2), pp.161 - 170. 10.1111/j.1751-3928.2008.00053.x . hal-00161201

\section{HAL Id: hal-00161201 \\ https://hal.science/hal-00161201}

Submitted on 10 Jul 2007

HAL is a multi-disciplinary open access archive for the deposit and dissemination of scientific research documents, whether they are published or not. The documents may come from teaching and research institutions in France or abroad, or from public or private research centers.
L'archive ouverte pluridisciplinaire HAL, est destinée au dépôt et à la diffusion de documents scientifiques de niveau recherche, publiés ou non, émanant des établissements d'enseignement et de recherche français ou étrangers, des laboratoires publics ou privés. 
Syntectonic mobility of supergene nickel ores of New Caledonia (Southwest Pacific). Evidence from faulted regolith and garnierite veins.

\title{
Dominique CLUZEL and Benoit VIGIER
}

Institut des Sciences de la Terre d'Orléans, ISTO, UMR 6113, University of Orleans, BP 6759, 45067 Orléans Cedex 2, France.dominique.cluzel@univ-orleans.fr

Running title:

\section{Syntectonic mobility of supergene nickel ores}

\begin{abstract}
Supergene nickel deposits of New Caledonia that have been formed in the Neogene by weathering of obducted ultramafic rocks are tightly controlled by fracture development. The relationship of tropical weathering and tectonic structures, faults and tension gashes, have been investigated in order to determine whether fractures have play a passive role only, as previously thought; or alternatively, if brittle tectonics was acting together with alteration. From the observation of time-relationship, textures, and mineralogy of various fracture fills and fault gouges, it may be unambiguously established that active faulting has play a prominent role not only in facilitating drainage and providing room for synkinematic crystallisation of supergene nickel silicate, but also in mobilising already formed sparse nickel ore, giving birth to the very high grade ore nicknamed "green gold".
\end{abstract}

Keywords : nickel, garnierite, faulting, veins, syntectonic, New Caledonia, Southwest Pacific. 


\section{Introduction.}

Supergene nickel ores formed by the weathering of ultramafic bodies represent about $42 \%$ of the global resources plus reserves and stand at ca. $160 \mathrm{Mt}$ nickel (Elias, 2002). New Caledonia retains about 7\% of this global amount and ranks fourth among world's nickel ore producers. Nickel concentration in the supergene environment results from the hydrolysis of olivine $(0.4 \mathrm{wt} \% \mathrm{Ni})$ and pyroxene $(0.025 \mathrm{wt} \% \mathrm{Ni})$ by weathering solutions and subsequent concentration as silicate minerals or adsorbed mineral phases in the lower part of the weathering profile. The lateritic profile developed on obducted peridotite in New Caledonia belongs to the hydrous Mg silicate type (Brand et al., 1998; Freyssinet et al., 2005) which are characterised by an absolute enrichment or concentration of $\mathrm{Ni}$ in the saprolite zone which comprises secondary serpentine, and neoformed goethite, smectite clays and garnierite. Much of the nickel is reprecipitated within the saprolite by substituting $\mathrm{Ni}$ for $\mathrm{Mg}$ in secondary serpentines (which can contain up to $5 \% \mathrm{Ni}$ ) and in garnierite which can grade over $20 \% \mathrm{Ni}$ (Pelletier, 1996). The weathering profile generally shows the following horizons from unweathered peridotite towards the surface: bedrock, rocky ore, ore with boulders, earthy ore, soft yellow limonite (Fe oxide-rich clayey soil), red limonite (a clayey soil containing minute Fe oxide granules) and finally cuirasse. In this paper, rocky ore, ore with boulders, and earthy ore will be referred to as saprolite, whereas yellow and red limonite which are geochemically and mineralogically most strongly altered, to as laterite. The present nickel deposits are the remnants of the large regolith that initially wrapped the whole island and was dissected during the recent episodes of positive epeirogenesis and sea level variation (Chardon \& Chevillotte, 2006; Chevillotte et al., 2006). Although the geology of supergene nickel deposits is apparently simple, deciphering the location of economically exploitable accumulations is still a challenge as ore grade and thickness vary laterally in a quite complex fashion depending upon local conditions.

The nickel ores in New Caledonia were formed during the Neogene (Chevillotte et al., 2006) by tropical weathering of the large ultramafic allochthon ("Nappe Ophiolitique" of Avias, 1967) that forms about $20 \%$ of the main island of New Caledonia. The ultramafic allochthon is composed of a main massif ("Grand Massif du Sud") located in the southernmost part of the island, and several tectonic klippes isolated by the erosion along the west coast (Fig. 1).The allochthon is composed of an harzburgite-dunite association that represents the mantle lithosphere of the Loyalty fore-arc basin which was obducted upon the northern tip of the Norfolk ridge, now represented by the main island of New Caledonia, in the latest Eocene (ca. 34 Ma; Cluzel et al, 1998; 2001). The overall structure of the ophiolite 
is very simple, the high-temperature foliation of the harzburgite and its basal thrust are nearly horizontal and only display kilometre-scale gentle folds. The uppermost part of the allochthon is represented by scarce ultramafic and mafic cumulates, which are preserved in restricted areas of the "Grand Massif du Sud" whereas oceanic crust components, e.g. isotropic gabbro, dyke swarm, and pillow basalt, are completely lacking, leaving the peridotite widely exposed at the surface. The tectonic structures related to the obduction of the ophiolite are mainly exposed in the tectonic sole which is composed of a low temperature, locally silicified porphyroclastic mylonite, 10 to 100m thick, and within the main body of the allochthon where numerous steeply dipping fractures crosscut the peridotite. Some of these fractures however post-date obduction as they offset the basal thrust. Most fractures are hectometre to kilometrescale faults which record a complex tectonic history that includes strike-slip, oblique and dipslip motion which has not yet been completely elucidated (Leguéré, 1976). Post-obduction deposits are rare and only a few Neogene marine sediments and poorly dated terrestrial deposits can provide time-controls on brittle tectonics (Lagabrielle et al., 2005; Chardon \& Chevillotte, 2006).

Among nickel mine geologists of New Caledonia, this is a common paradigm to consider that the nickel ore was formed by weathering of pre-fractured peridotite, and that fracturing mainly occurred before and during the Late Eocene obduction. Indeed, fracture development is of major importance on the development of regoliths (Leguéré, 1976; Elias, 2002), and ore thickness is usually controlled by fractures, but we have noticed that the regolith is often faulted and striated; fractures of doubtless tectonic origin are filled with supergene silicates, and fault gouges may contain garnierite fragments and are in turn cemented by garnierite (Vigier, 2001). These findings infer that tectonic events occurred during the formation of Nirich supergene material. In this paper we explore the relationships between the brittle tectonic structures and generation of weathering profiles as they involved the formation of fractures filled with alteration products. We also investigate the texture and mineralogy of garnierite vein fills and compare it with well known examples of syn-kinematic mineral development in brittle and semi-brittle fracture zones in order to propose a mechanism for syntectonic reconcentration of supergene nickel.

Analytical methods. Identification of mineral phases has been conducted using an INEL RG 3000 X-ray diffractometer fitted with a CPS 120 curved detector. Chemical compositions of individual mineral grains have been determined on polished thin sections by using a Cameca SX50 electron microprobe at the BRGM-CNRS analytical pool of Orleans. 
Garnierite ore. In 1867, Jules Garnier wrote: « Rocks cavities are filled with a magnesian silicate strongly coloured by a nickeliferous matter ... » about spectacular grass-green nickel ores he had discovered in New Caledonia. A few years later, nickel mining started in the Thio Plateau area (East coast). In these early times, only high grade ore (the so-called "green gold") was hand-mined from superficial rock cracks; and the colourful nickel-rich ore was named garnierite in the honour of its discoverer. Quickly, workable garnierite veins became rare and lower grade ores (saprolite at ca. $2.5 \% \mathrm{Ni}$ content) formed the bulk of the resource; however, the occurrence of garnierite is still taken as a guide to mineralised areas. Although discovered by Jules Garnier in 1864, garnierite was described much later during the second half of 20th century thanks to the development of X-ray diffraction and other analytical methods. Actually, garnierite is not a mineral but an admixture of three solid solutions (serpentine, talc and smectite) that all vary in composition between magnesian and nickeliferous end-members (Caillère, 1965; Maksimovic, 1966; Brindley, 1973), the six end-members of the mixture are:
a. serpentine family
pecoraite : $\mathrm{Ni}_{3}\left(\mathrm{Si}_{2} \mathrm{O}_{5}\right)(\mathrm{OH})_{4}$
lizardite : $\mathrm{Mg}_{3}\left(\mathrm{Si}_{2} \mathrm{O}_{5}\right)(\mathrm{OH})_{4}$
b. smectite family
pimelite : $\mathrm{Ni}_{2}\left(\mathrm{Si}_{4} \mathrm{O}_{10}\right)(\mathrm{OH})_{4} \mathrm{n} \mathrm{H}_{2} \mathrm{O}$
kerolite : $\mathrm{Mg}_{2}\left(\mathrm{Si}_{4} \mathrm{O}_{10}\right)(\mathrm{OH})_{4} \mathrm{n} \mathrm{H}_{2} \mathrm{O}$
c. talc family
willemseite : $\mathrm{Ni}_{3}\left(\mathrm{Si}_{4} \mathrm{O}_{10}\right)(\mathrm{OH})_{2}$
talc : $\mathrm{Mg}_{3}\left(\mathrm{Si}_{4} \mathrm{O}_{10}\right)(\mathrm{OH})_{2}$

Mine geologists generally call "garnierite" any green, Ni-rich, mineral phase and "dewellite" any whitish material that generally contain only a few \% Ni (Fig. 2). The nickeliferous serpentine end member is often called "nepouite" (Pelletier, 1996). On a geochemical basis, it is possible to evaluate the proportion of the diverse components of the mixture by using the $\mathrm{NiO} / \mathrm{NiO}+\mathrm{MgO}$ ratio (Manceau et al., 1985). Many other minerals are present in the nickel ores of New Caledonia, most of them are silicates (e.g. montmorillonite, sepiolite, amesite, chlorite, and phlogopite), and oxides (e.g. limonite) that may bear variable amounts of $\mathrm{Ni}$ (a few tens of \% up to 40\%) and all display a typical green colour. 


\section{Tectonic controls on fracture development and evidence for syntectonic weathering.}

Fractures bear some importance on the development of regoliths because peridotites are generally very massive and unless strongly fragmented, do not provide much room for circulating waters. It has been noted for a long time that ore thickness and locally ore grade are partly controlled by fractures (Leguéré, 1976); however, the possibility for active faulting to have controlled nickel mobility has not really been considered. Two kinds of faults are generally found in nickel mines; most of them are rooted in the bedrock and are likely due to the reactivation of older faults; the others are very shallow dipping faults restricted to the lateritic profile. Bedrock-rooted faults are generally steeply dipping in the peridotite and shallower in the regolith; this feature is due to the changing mechanical behaviour of the progressively weathered material. At the very low confining pressure that corresponds to subsurface environment of regoliths, the cohesion and shear strength of moderately weathered peridotite are high so that the shear angle $(\theta)$ related to normal faulting (e.g. $\sigma_{1}$ vertical and $\sigma_{3}$ horizontal), is within the range of $70-80^{\circ}$. In contrast, in highly weathered peridotite (saprolite) and in softer laterite, cohesion and shear strength decrease rapidly upwards and the shear angle diminishes to ca. $45^{\circ}$. Near the surface, the orientation of the main stress directions (the axes of the stress ellipsoid) closely depends on topographic features and the orientation of minimum stress $\sigma_{3}$ may vary at short distances resulting in changing fracture sets and slip vector on fault planes. Of course, the present topography is most likely to be different to that at the time of active tectonics and no direct correlation to the local stress field is still possible. Where fractures unambiguously rooted in the basement have been examined, the parts of the fault located in the bedrock displays several episodes of motion (e.g. three or four overprinted striations); in contrast, the faulted regolith located above generally display one or two striations only. Thus, it may be considered that most faults observed in open pit nickel mines are due to the reactivation of older faults.

In addition to changing shear strength, slope failure can play an important role on shallow fracture development above active faults. Very shallow dipping $\left(0-15^{\circ}\right)$ fractures are generally located within the saprolitic horizon at the interface of the bedrock and regolith. They display the same mineralogical and textural features as the steeper faults; e.g. striated and duplexed supergene material such as dewellite (Fig. $2 \mathrm{~b} \& 3$ ). As they are not directly connected to basement faults, they are most likely due to slope failure on top of active faults. Active faults generate very steep slopes that allow the base of the weathering profile to be exposed. An instable cliff composed of low shear strength material may then trigger slope failure and formation of a semi-circular lens that may remain within the laterite, or reach the saprolite 
horizon depending upon the initial throw of the fault. It is worth noting that circulating waters may greatly reduce the shear strength of the saprolite horizon and thus favour slope failure. At present however, the recent erosion has profoundly changed the original topography, and it is not always possible to relate any shallow dipping fracture to its "mother fault".

Evidence for long lasting syn-tectonic weathering is provided by faults which are now located in the upper part of nickel deposits, generally within or near the laterite horizon. These faults are marked by crossing striations indicating repeated motions with different kinematics, and display complex gouges, the composition of which may be related to increasingly shallow conditions. A typical example has been observed at the Byzance quarry of Camp des Sapins mine (Thio) where an E-W trending normal fault zone less than two metres thick is exposed. This fault zone is composed of several parallel surfaces that define a compositional zoning. From the footwall to the hangingwall, we have distinguished:

a. an almost unweathered peridotite coated by slickensided serpentine (lizardite or antigorite);

b. a normal-sinistral slickensided dewellite surface resting upon saprolite ;

c. a normal (dip-slip) slickensided garnierite resting upon striated saprolite and dewellite ;

d. a breccia made of a slightly foliated laterite matrix containing small garnierite clasts. The upper surface of the breccia displays a thin striated iron oxide varnish with a normal-dextral motion ;

e. the hangingwall of the fault formed of slickensided dark green garnierite underlying a gently weathered saprolite with a boxwork structure filled by garnierite.

It clearly appears that in contrast with previous thoughts, it is not certain at all that any fracture development predates supergene alteration and Ni mobilisation. It is worth to note that the nature of fracture fills generally change with that of the enclosing material: grassgreen garnierite is generally restricted to Ni-rich saprolite, whereas dewellite is mainly developed near the interface between saprolite and unweathered peridotite, and laterite represents the upper part of the alteration profile. Thus, the coexistence of components of the three weathering horizons within one single fault zone and that of garnierite clasts within striated laterite infer that faulting occurred repeatedly while alteration was prograding downwards. 


\section{Mode of occurrence of garnierite veins.}

Garnierite is generally interspersed with other weathering products within saprolite that retains the higher Ni contents; alternatively, it may appear alone in $\mathrm{mm}$ to cm-thick veins. Compared with saprolite that only contains 2-5 wt\% Ni, garnierite veins may held up to 25-40 wt\% $\mathrm{Ni}$, thus forming anomalously rich zones. Garnierite also occurs below the saprolite horizon in unweathered peridotite as vein fills and seams on fracture surfaces.

Garnierite mineralization appears as either syn-kinematic or post-kinematic fracture fills. Several field occurrences may be distinguished on the basis of textural relationships to the enclosing fracture: i) sub-parallel or en-echelon tension cracks, ii) thin coatings on joints (< 0,1 mm) (referred to as "paints" by miners), iii) boxwork fabric, iv) garnierite-bearing fault breccia, v) slickensided fault coatings, and vi) syn-kinematic fibrous growths within fault planes.

Tension cracks are generally developed in moderately weathered saprolite but scarce examples of garnierite-bearing tension cracks occurring in laterite (Nakety mine) and in unweathered peridotite actually exist, the latter most probably result from the opening of preexisting fractures. Tension cracks are generally a few $\mathrm{cm}$ to $50 \mathrm{~cm}$ long and a few $\mathrm{mm}$ to a few cm wide; they are sometimes arranged in en-echelon arrays (Beach, 1975) (Fig. 2c \& 2d). They have been commonly formed during several tectonic events and display crosscutting relationship (Fig. 2e). They may be filled with colloform (botryoidal) or amorphous material or both. In most occurrences, an early colloform garnierite (diagnostic of mineralised open spaces) is located along the borders of the fracture while amorphous material forms the more internal infill (Fig. 4a and 4b). Locally, the colloform material is fractured and brecciated and the fragments are coated by a second generation of colloform garnierite, or more frequently by amorphous material (Fig. 4c). These nickel-rich crack fillings are in turn crosscut by thin tension cracks filled with chalcedony or microcrystalline quartz that roughly follow the middle of the older fracture and cut the amorphous and colloform material as well (Fig. 2e \& 4a). This infers the polyphase character of syntectonic mineralization in changing chemical conditions.

Colloform garnierite is composed of the serpentinite component nepouite (intermediate between pecoraite and lizardite) and the talc component willemseite. A microprobe analysis across tension cracks filled with colloform material reveals that the Ni content displays a symmetrical variation across the fracture (Fig. 5); in contrast, the composition of amorphous material is more or less constant (not represented). 
Most cracks filled with colloform garnierite only, display an homogeneous green colour, are nickel-rich, and thus are likely to have been formed during one single episode; in contrast, fractures filled with amorphous material only, that may also have an homogenous green colour indicative of a relatively constant $\mathrm{Ni}$ content, locally display a vertical gradation within a few decimetres from whitish, almost nickel-free "dewellite" (an admixture of lizardite and talc) at the base, changing upwards into grass green "garnierite" (pecoraite and willemseite). Such a gradation is likely to be due to the secondary enrichment of an already filled crack by circulating nickel-bearing solutions. No such features were observed in fractures filled with colloform garnierite, the nickel content of which is primary.

Box work fabric ("minerai quadrillé" of mine geologists) appears as a three-dimensional network of sub-orthogonal fractures that abut against each other and delineate orthorhombic elements a few $\mathrm{cm}$ or dm in size. Millimetre-thick tension cracks are filled with garnierite and microcrystalline quartz, the latter being always deposited later (as in most tension cracks), either as crosscutting fractures, or in the centre of garnierite-filled veins. It is worth noting that some garnierite-filled fractures crosscut each other and display slightly different contents and/or texture which infer that fracture development occurred in a changing stress field. Thus, the "minerai quadrille" can no longer be considered to result from the mineralization of preexisting fractures. A box work fabric mainly develops near faults and may be interpreted as a dilatational feature that occurs near the end of a fault or in a relay zone between two enechelon faults. A systematic analysis of fracture orientation reveals that they are arranged in a sub-orthogonal fashion as mentioned above near the associated fault and become less regular at distance depending upon small scale variation of the local stress field and/or pre-existing heterogeneities of the rock mass.

Among the small-scale faults that are widespread in nickel mines, many are barren and only filled with serpentine, silica, and/or laterite gouges; but some others display well developed garnierite mineralization. Garnierite may be present as either garnierite cement of fault gouges; or alternatively, garnierite clasts. The former appear when the nickel saturation zone has reached a pre-existing fault breccia. Generally, serpentine clasts are coated with colloform garnierite that has been deposited in a relatively static (i.e. post-kinematic) fashion. In contrast, the occurrence of garnierite clasts implies the tectonic remobilisation of a preexisting fracture fill. Garnierite clasts are often crosscut by quartz/chalcedony veinlets and are generally surrounded by a slickensided laterite matrix. 
Slickensides are a common feature of brittle and semi-brittle tectonics, they are related to a strongly partitioned shearing deformation and form along rock surfaces as a result of friction along a fault plane. Polished and striated surfaces are widespread in nickel mines and some of them can be followed on a few tens of metres across the weathering profile. Striated fault planes that develop in saprolite near the bedrock are often coated by green fibrous synkinematic nepouite (Fig. 2a) (see below), or whitish "dewellite" (Fig. 2b), or both. The striated dewellite coating is formed of crumbled amorphous material (Fig. 4d) which in places, forms decimetre-thick imbricate structures similar to out-of-sequence duplexes (Fig. 3a). In the upper part of the profile, glossy striated surfaces that are found in laterite (Fig. 2f) have often been mistaken as an effect of truck or charger overload during ore extraction. However, most of these surfaces are real faults rooted in saprolite and locally in the bedrock; they locally display a very thin striated iron oxide varnish, and rarely but significantly contain small serpentine and/or garnierite fragments. Slickensided surfaces commonly display two or more slip directions marked by crossing striations; the most common features are dip-slip and related to normal faulting (Fig. 2b), but oblique or strike-slip movements are not uncommon (Fig. 2a). In the Thio Plateau mine site (east coast) dip-slip motion is followed by a younger oblique slip event. Thus, an anthropogenic or landslide-related origin may be ruled out.

Syn-kinematic fibrous growths that generally occur in rocks during the opening of tension crack (crack-seal mechanism) and small-scale fault motion (microfaulting) is generally taken as a compelling evidence for relative motion along faults. In most cases, the mineralogy of synkinematic fibres is closely related to the chemical composition of host rock (Durney, 1972; Baghat \& Marshak, 1990) indicating a close local origin for the circulating solutions. Synkinematic fibre growth is extremely common in tectonised serpentinised peridotite and slickensided faults in the bedrock are often coated with fibrous lizardite or chrysotile. Fibrous nepouite coatings have been found in many nickel mines and may be located within tension gashes, and strike-slip or normal faults as well. On thin sections cut perpendicular to the microfault and parallel to the fibre length, nepouite fibres are continuous from one side of the fracture to the other and clearly appear to have crystallised during oblique motion (Fig. 4e \& 4f). Some thicker fibres have undergone microboudinage and develop minute tension cracks perpendicular to the fibre axis (Fig. 4f); this is a common feature of synkinematic fibre growths (i.e. calcite or quartz) and appears when the rate of fibre growth does not allow the mineral to filling all the available space. In some cases, older garnierite-filled tension cracks have been reactivated by either normal or strike-slip shearing and synkinematic fibres develop 
over colloform garnierite (Fig. $4 \mathrm{~g}$ and $4 \mathrm{~h}$ ). In all studied samples, silica represents the youngest mineral phase and fills either tension cracks that orthogonally crosscut the colloform and fibrous material (Fig. 4g), or fractures parallel to the fibres (Fig. 4h). Late quartz veinlets may be in turn tectonised and display striation or microboudinage (Fig. 4h)

\section{Discussion.}

From the evidence presented above, it may be inferred that faulting was active during the tropical weathering of obducted ultramafic rocks. This inference is consistent with that of Lagabrielle et al. (2005), and Chardon \& Chevillotte (2006) who have shown that Neogene marine sediments, regoliths and fluviatile sediments derived from the erosion of regoliths, have been similarly affected by brittle tectonics. It clearly appears that the supergene nickel ore is both under lithological and tectonic control; the latter is especially marked by garnierite concentration within fractures. For a better understanding of the role of brittle tectonics, it is better to consider the three possible mineralizing processes separately, although they are tightly linked, e.g.: i) ore localisation, ii) solution drainage, and iii) remobilisation.

The occurrence of nickel ore in open cavities is a normal consequence of nickel-saturated fluid migration through an already fractured rock. It obviously appears that some of the fractures filled with colloform garnierite and related material were already present in the rock. However, polymineral fillings need actively opening cracks to allow different mineral phases to be emplaced within open spaces. In addition, the syntectonic emplacement of nickel mineralization is confirmed by the occurrence of crack-seal crystallisation.

The development of fracture sets enhances the infiltration and mobility of superficial waters (tectonically controlled drainage); in addition, the occurrence of a dense fracture network increases the rock surface which is submitted to hydrolysis. More over, a better drainage allows the removal of dissolved material and allows more chemically active waters to circulate. In contrast, active tectonics and formation of open cracks makes room for new material to crystallise.

As a residual element, nickel cannot move far away from its original location and the occurrence of relatively large amounts of nickel silicate in veins needs an enhanced mobilisation process; therefore, we suggest that as in similar tectonic environments, a selective dissolution of some minerals may be enhanced by pressure or shear solution (tectonically-controlled mobilisation). Basically, pressure solution is the process wherein minerals dissolve as the result of pressure applied externally to them. This may happen because minerals under pressure (and thus undergoing elastic strain) are more soluble than 
unstressed minerals, and/or because deformation (permanent strain) due to stress leaves minerals more soluble. At the microscopic scale, pressure dissolution occurs at contacts between grains, because stress is localized at grain contacts if surrounding pore volumes support no load. Intergranular dissolution generates solutions that may be precipitated in nearby pores, occluding porosity and eventually precluding further intergranular pressure dissolution. Intergranular pressure dissolution may also stop as the areas of grain contacts expand to provide surfaces sufficient to support the force previously focused on smaller areas at greater stress. In that case, remaining intergranular pore space may be filled by cements precipitating by transporting fluids. A reduced porosity and increasing strain may result in local fluid overpressure that in turn may generate hydraulic fractures (Gravilenko \& Gueguen, 1993) in which dissolved minerals precipitate (for a review on pressure solution, see Durney, 1972; Kerrick, 1977; De Boer, 1977; Engelder et al., 1981; Guzetta, 1984; Groshong, 1988; Gratier, 1993; Lehner, 1995; and references herein). The occurrence of tension cracks filled with locally-derived minerals (calcite, quartz, gypsum) is a common feature in brittle and semi-brittle rocks and has been systematically related to pressure solution in the closely adjacent rocks. Thus, the distance covered by dissolved material is in general not greater than a few centimetres or decimetres, depending upon the permeability of the material (Baghat \& Marshak, 1990). In the case of nickel/magnesium silicates (garnierite/dewellite), the local stress conditions induced by the formation of a fracture network, or a nearby fault, may result in remobilisation of already precipitated material. Thus, depending upon local chemical features of the considered weathering horizon, nickel-saturated or nickel-free supergene silicates may form in open spaces.

Conclusion. The occurrence of fractures filled with synkinematic supergene material in the nickel deposits of New Caledonia infer that active tectonics and tropical weathering were acting together during the Neogene. The role of active tectonics was not only to enhance peridotite weathering by facilitating water circulation, but it also contributed to nickel concentration by creating new open spaces, and most likely remobilised already formed sparse nickeliferous mineral phases to finally result in very high grade ores.

Acknowledgements. Special thanks are due to ERAMET-SLN and SMSP-Falconbridge mine geologists for permission to work in the mines, welcome, housing and introducing the geology of Thio and Koniambo nickel mines. BV travel expenses to New Caledonia have been partly supported by a grant of the Institut Français du Pétrole to DC. Aknowledgements 
are also due to Dr N. Skorpelis for his accurate review and constructive comments on an earlier version of the manuscript. 


\section{References}

Avias, J. (1967). Overthrust structure of the main ultrabasic New Caledonian massives, Tectonophysics, 4, 531-541.

Baghat, S.S., and Marshak, S. (1990) Microlithon alteration associated with development of solution cleavage in argillaceous limestone: textural, trace-elemental and stable-isotopic observations: Journal of Structural Geology, 12, 165-175.

Beach A. (1975) The geometry of en-echelon vein arrays. Tectonophysics, 28, 245-263.

Brand, N.W., Butt, C.R.M., and Elias, M. (1998) Nickel laterites: Classification and features: AGSO Journal of Australian Geology and Geophysics, 17, 81-88.

Brindley G.W and Pham Thi Hang (1973) The nature of garnierites - I. Structures, chemical compositions, and color charcteristics. Clays clay minerals, 21, 27-40.

Caillère S. (1965) Composition minéralogique des divers types de minerais de nickel de la Nouvelle-Calédonie. Mém. Museum Hist. Nat. Paris, 12 (3), 106-124.

Chardon D. and Chevillotte V. (2006) Morphotectonic evolution of the New Caledonia ridge (Pacific Southwest) from post-obduction tectonosedimentary record. Tectonophysics, 420, 473-491.

Chevillotte V., Chardon D., Beauvais A., Maurizot P., and Colin F. (2006) Long-term tropical morphogenesis of New Caledonia (Southwest Pacific): Importance of positive epeirogeny and climate change. Geomorphology 81, 361-375.

Cluzel D., Chiron D. and Courme M.D. (1998) Discordance de l'Eocène supérieur et événements pré-obduction en Nouvelle-Calédonie (Pacifique sud-ouest) C. R. Acad Sci. Paris., 327, 485-491.

Cluzel D., Aitchison J.C., and Picard C. (2001) Tectonic accretion and underplating of mafic terranes in the Late Eocene intraoceanic fore-arc of New Caledonia (Southwest Pacific). Geodynamic implications. Tectonophysics, 340, 1-2, 23-60.

De Boer, R.B. (1977) Pressure solution: Theory and experiments: Tectonophysics, 39, 287-301.

Durney, D.W. (1972) Solution-transfer, an important geological deformation mechanism: Nature, 235, 315-317.

Elias, M. (2002) Nickel laterite deposits - geological overview, resources and exploitation, In: Giant Ore Deposits: Characteristics, genesis and exploration, Eds: D.R. Cooke and J. Pongratz. CODES Special Publication 4, Centre for Ore Deposit Research, University of Tasmania, 205-220. 
Freyssinet, P., Butt, C.R.M., Morris, R.C., and Piantone P. (2005) Ore-forming processes related to lateritic weathering. Society of Economic Geologists, Inc. Economic Geology 100th Anniversary Volume, 681-722.

Engelder, T., Geiser, P.A., and Alvarez, W. (1981) Role of pressure solution and dissolution in geology. Geology, 9, 44-45.

Gavrilenko, P., and Gueguen, Y. (1993) Fluid overpressures and pressure solution in the crust: Tectonophysics, 217, 91-110.

Geiser, P.A., and Sansone, S. (1981) Joints, microfractures, and the formation of solution cleavage in limestone: Geology, 9, 280-285.

Gratier, J. P. (1993) Le fluage des roches par dissolution sous contrainte, dans la croûte supérieure. Bull. Soc. Géol. Fr., 2, 267-287.

Groshong, R.H., Jr. (1988) Low-temperature deformation mechanisms and their interpretation: Geological Society of America Bulletin, 100, 1329-1360.

Guzetta, G. (1984) Kinematics of stylolite formation and physics of the pressure-solution process: Tectonophysics, 101, 383-394.

Kerrick, R. (1977) A historical review and synthesis of research on pressure solution: Zentralbl. Geol. Paläont. Teil I, 512-550.

Lagabrielle Y., Maurizot P., Lafoy Y., Cabioch G., Pelletier B., Régnier M., Wabete I., and Calmant S. (2005) Post-Eocene extensional tectonics in Southern New Caledonia (SW Pacific): insights from onshore fault analysis and offshore seismic data. Tectonophysics, 403, $1-28$.

Leguéré J. (1976) Des corrélations entre la tectonique cassante et l'altération supergène des péridotites de Nouvelle Calédonie. PhD thesis, University of Montpellier, France, 95p.

Lehner, F.K. (1995) A model for intergranular pressure solution in open systems: Tectonophysics, 245, 153-170.

Maksimovic Z. (1966) $\beta$-kerolite-pimelite series from Goles Mountains, Yugoslavia. Proc. Int. Clay Conf., Jesusalem 1, 97-105.

Manceau A., Calas G. and Decarreau A. (1985) Nickel-bearing clay minerals: I. Optimal spectrometric study of nickel crystal chemistry. Clay Minerals, 20, 367-387.

Pelletier B. (1996) Serpentine in Nickel Silicate Ore from New Caledonia. In: Nickel '96: mineral to market (Grimsey, E.J. and Neuss, I., Editors), The Australasian Institute of Mining and Metallurgy, Publication series 6/96, 197-205.

Vigier B. (2001) Caractère syntectonique des minéralisations nickélifères supergènes de Nouvelle-Calédonie. Unpubl. MSc thesis, University of Orleans, France, 38 p. 


\section{Figure legends}

Figure 1 : geological sketch map of the ultramafic allochthon of New Caledonia (in gray) (after Avias, 1967) and location of studied nickel mine sites.

Figure 2 : outcrop pictures of representative tectonic features of nickel mines. 2a: synkinematic nepouite (?) on a strike-slip fault (Koniambo mine), the bar is parallel to the striation; 2b: gently dipping normal fault with slickensided dewellite (Thio plateau mine); 2c: parallel and en-echelon tension cracks filled with grass-green garnierite (Thio-Camp des sapins mine); 2d: en-echelon tension cracks filled with synkinematic "dewellite" (crack seal texture) (Koniambo mine); 2e: a polyphase garnierite vein with a central part formed of light brown silica crosscut by a thick silica vein; 2f: striated laterite (Thio-Camp des sapins mine) the bar is parallel to the striation (normal-dextral motion); $2 \mathrm{~g}$ : basement rooted fault, on the left side, the footwall is composed of gently weathered peridotite; the right side is a serpentinitic fault gouge; $2 \mathrm{~h}$ : an enhanced detail of Fig. $2 \mathrm{~g}$ to show a decimetre-size pocket of striated laterite breccia containing small serpentinite and garnierite clasts.

Figure 3 : outcrop pictures of shallow faults with tectonically deformed supergene silicates; 3a: shallow dipping normal fault to show a thick (ca. $80 \mathrm{~cm}$ ) "duplexed" dewellite fill arranged in a scally fashion, the hangingwall and footwall of the fault are both composed of saprolite (Trois Tonneaux quarry, Thio mine); 3b: shallow dipping fault and "duplexed" dewellite in highly weathered reddish saprolite (seaside road South of Thio village).

Figure 4 : photomicrographs of representative thin sections under polarised light. 4a: colloform garnierite fracture fill crosscut by younger silica-filled anastomosed tension cracks; 4b: a tension crack in saprolite with symmetrical ribbons of colloform garnierite typical of open fracture filling; 4c: brecciated colloform garnierite, note the thin colloform coating on garnierite fragments (arrows), the amorphous garnierite matrix of the breccia and the subsequent tension cracks also filled with amorphous garnierite; 4d: "crumbled" dewellite in a microfault, note the thin colloform garnierite coating within open cavities; 4e: oblique synkinematic fibres of nepouite (crack seal texture), 4e1: polished section parallel to the fibres, 4e2: thin section, polarized light; 4f: enhanced detail of Fig. 4e2, the arrow shows microboudinaged fibres; 4g: synkinematic fibrous garnierite (nepouite ?) after colloform garnierite in a tension crack reactivated as a normal micro-fault, note the minute tension cracks filled with silica (arrow) that crosscut the synkinematic fibres; 4h: polyphase fracture with in the order of appearance: i) colloform garnierite, ii) synkinematic fibrous garnierite, iii) silica-filled tension cracks (mainly located in the centre of the fracture), and iv) microboudinage of the latter. 
Figure 5 : Electron microprobe transect through a colloform garnierite vein (Koniambo mine) showing a symmetrical variation of nickel content due to the progressive filling of an open crack under fluctuating chemistry of weathering solutions. Similar profiles have been obtained from colloform veins of different sites; in contrast, amorphous fillings show no decipherable variation (not represented).

Figure 6 : An idealised view of the development of boxwork structure at the end of a normal fault. 


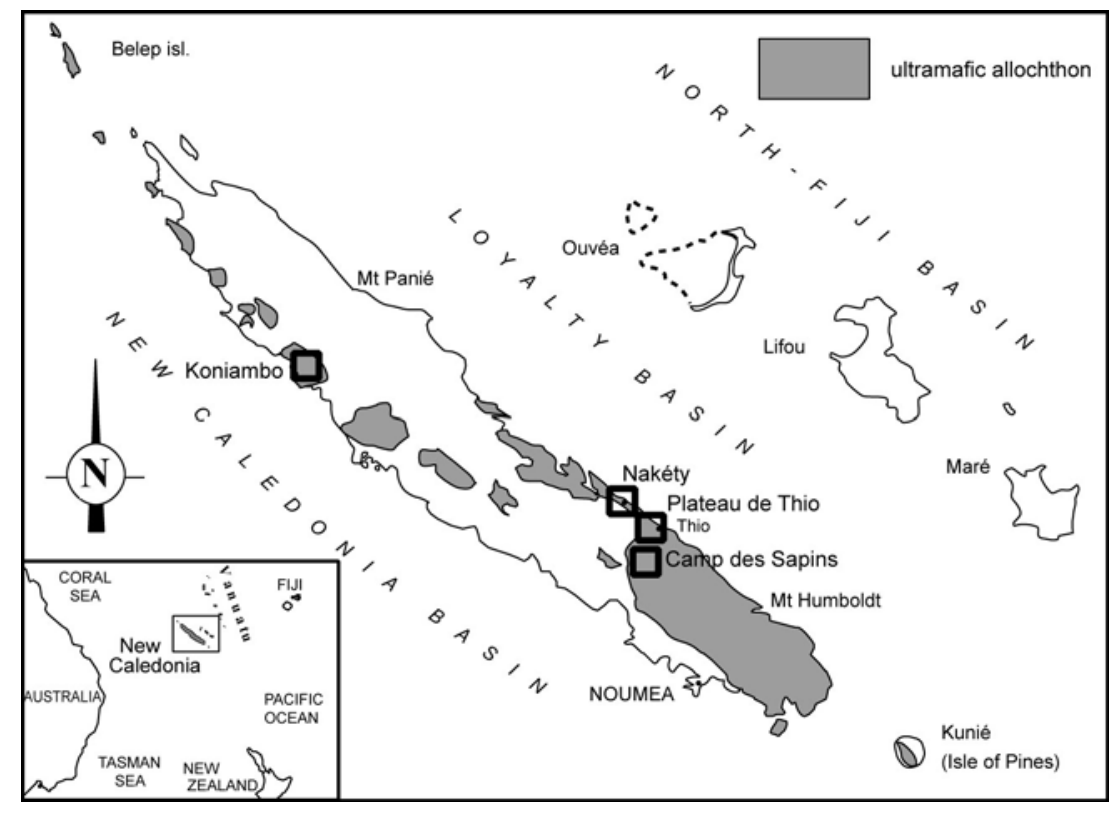

Figure 1 

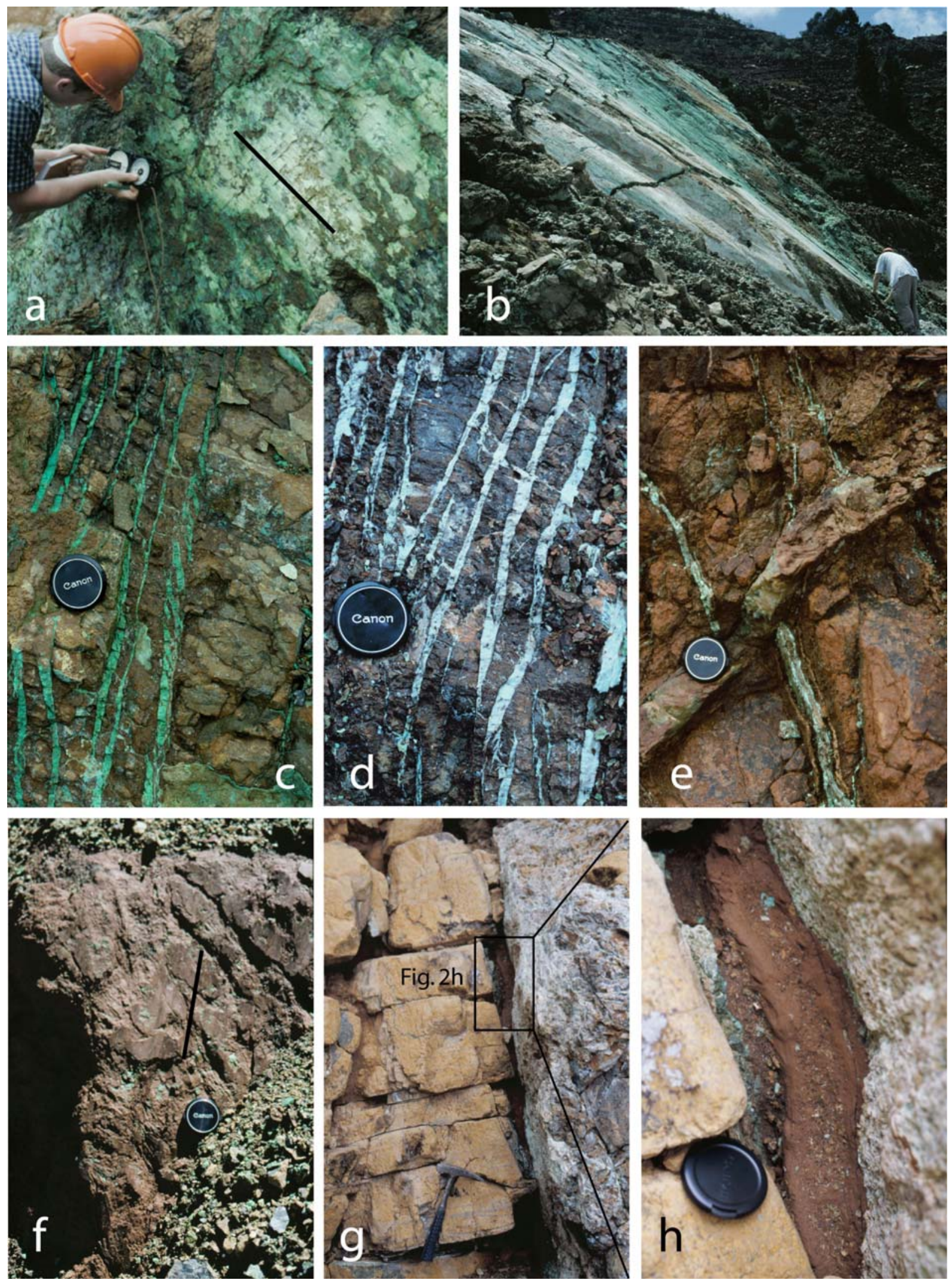

Figure 2: field pictures 

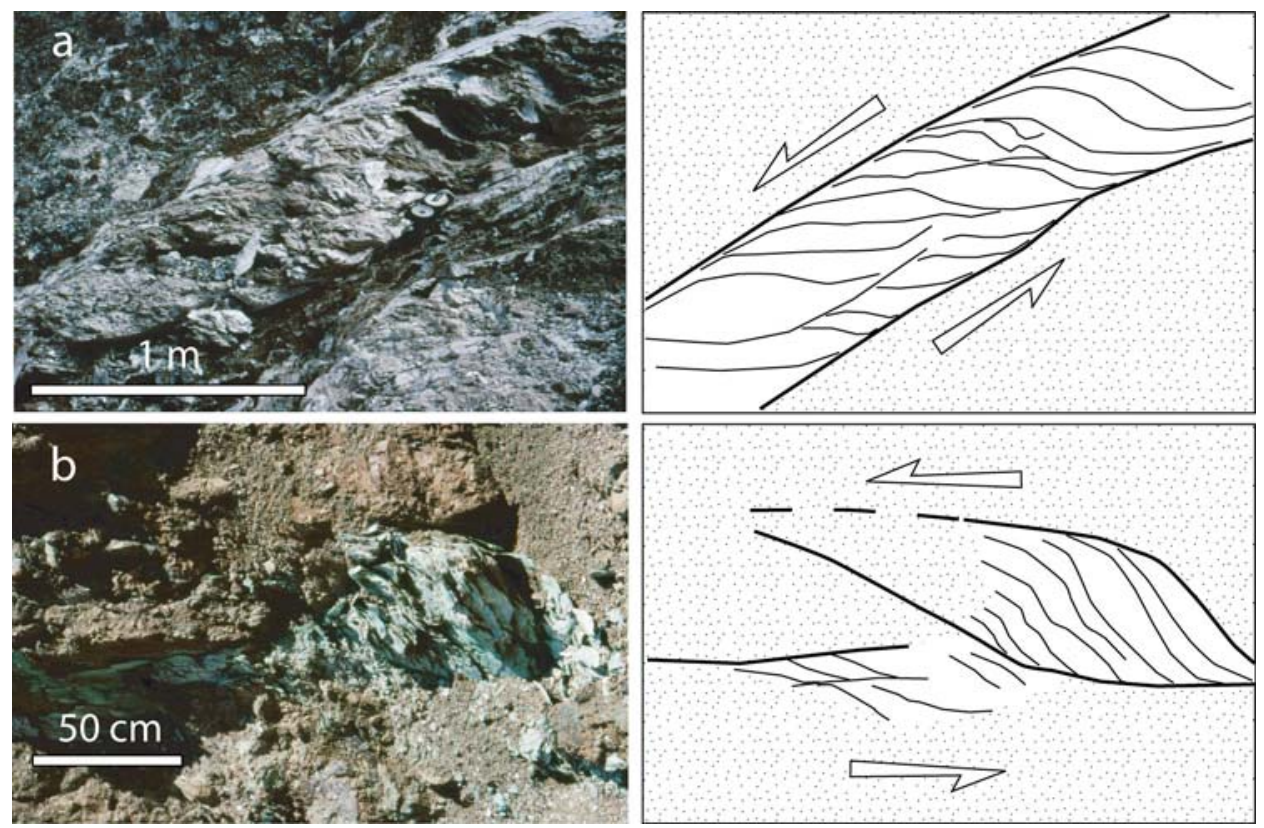

Figure 3 

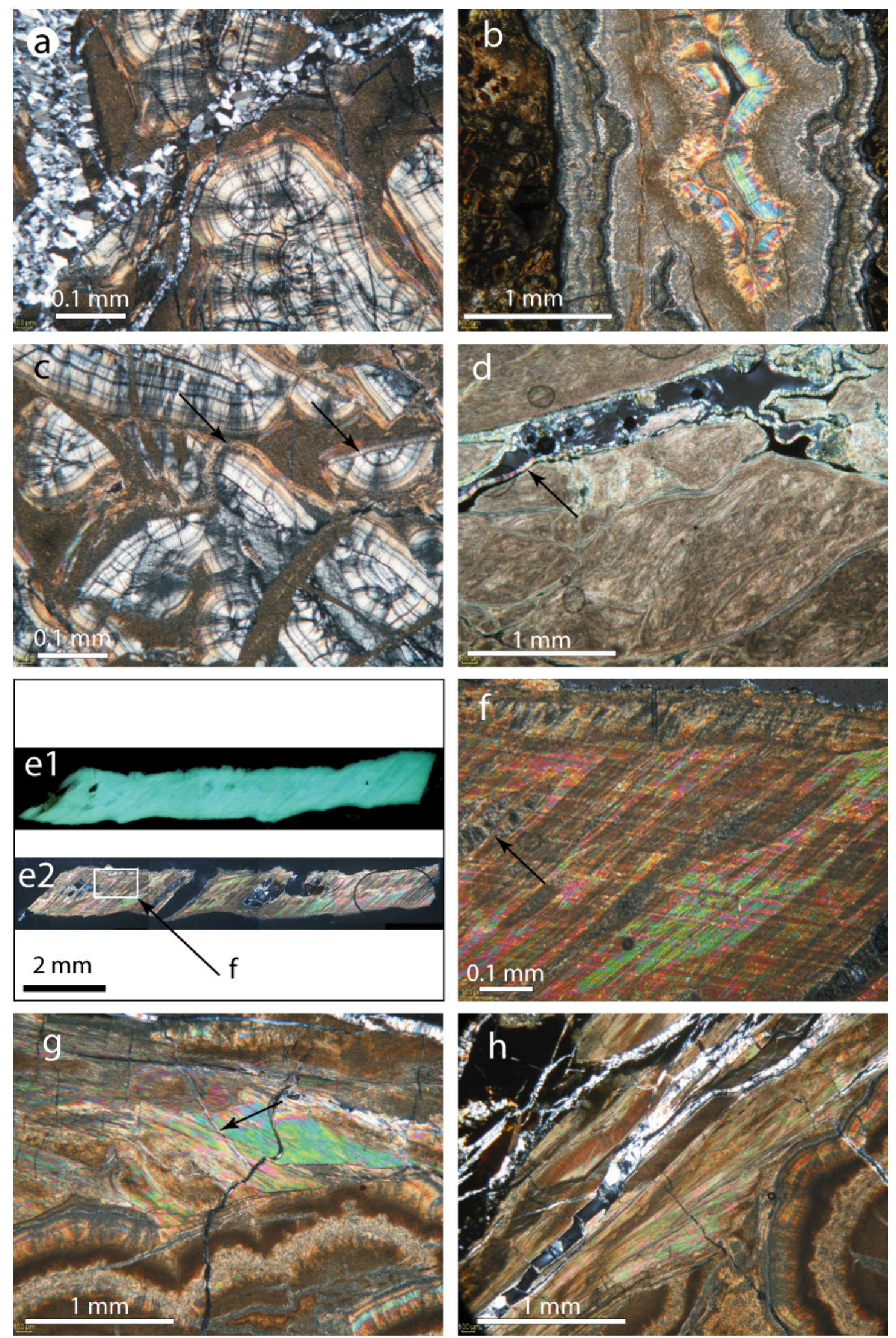

Figure 4: photomicrographs 


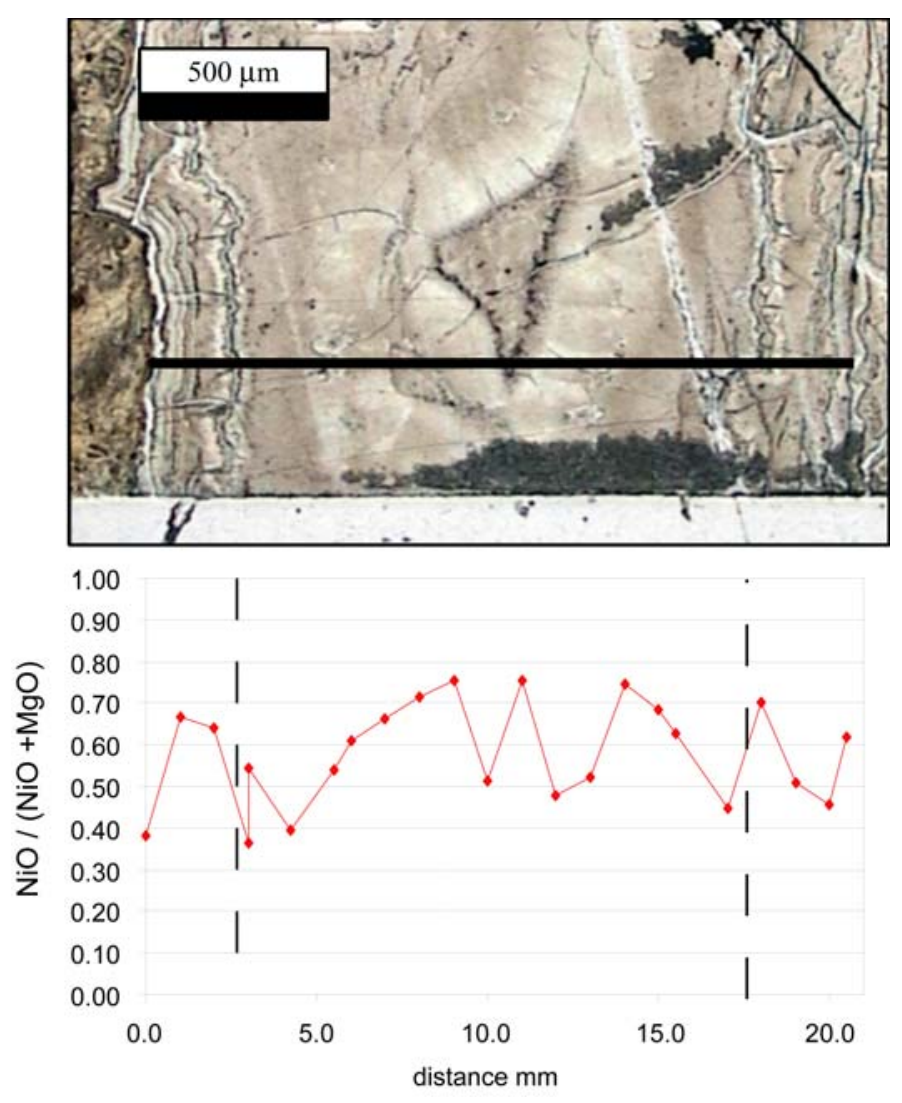

Figure 5: microprobe transect 


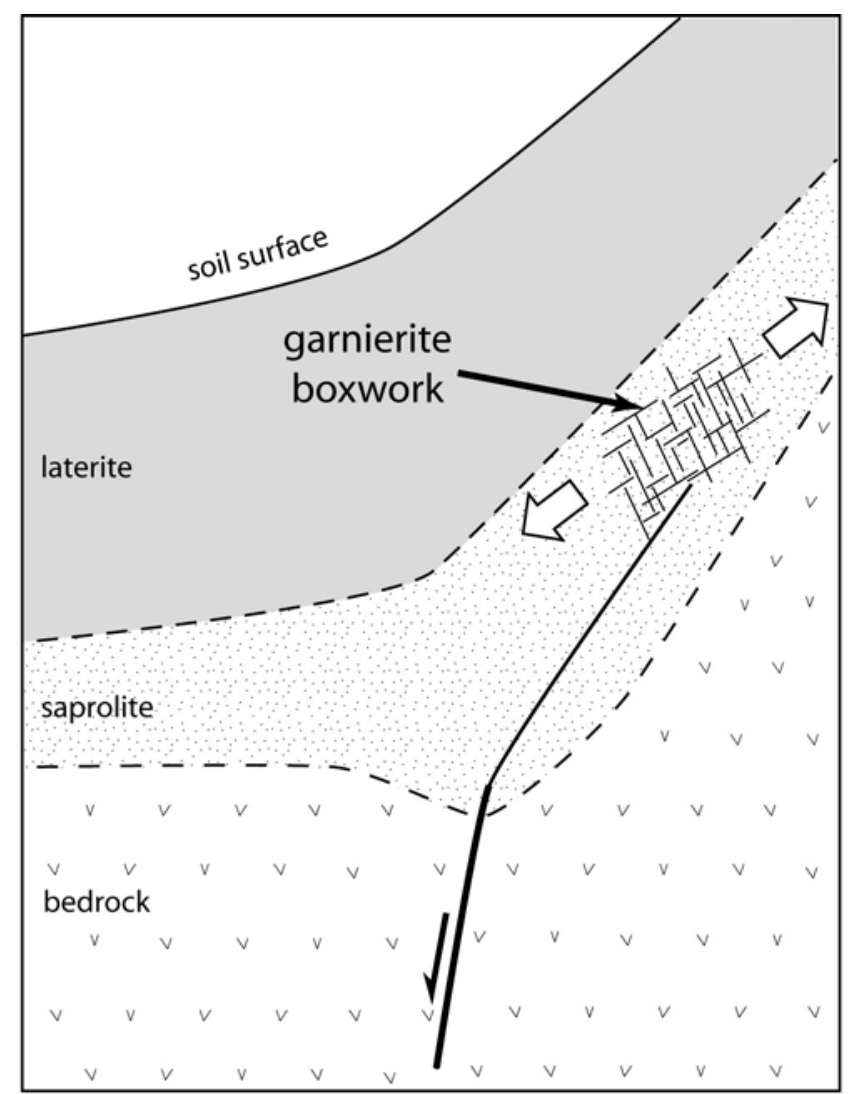

Figure 6 : Development of boxwork structure at the end of a normal fault 